以上のように,エンジ開度の相違による DL 型粉羭 の散布所要特間抢よび蒋剂の落下分散には注とんど差が みられなかったが，エンジン開度を下げた場合には莧剤 の下部到達性が悪くなり，トビイロウンカの防除効梨の 劣ることが琶めら扎たこれは，エンシン開度すなわち エンシン回転数が防除效果に関係していること示すを のであり，エンシン開度の低下は楽剤の下部到達および 稻株への付着に必要な風量が不足し, 防除效果を不安定
にするものといえる。したがって，DL 型粉㓮の教倠に おいては、エンジン開度すなわちエンジン可茜数を可能 な範冊で大きくすることが望ましいものと考察される。

\section{引用 文献}

1）野中耕次・永非清文・後藤画喜（1980） 儿病虫研会 報 $26: 112$ - 114 . (1980年 5 月 8 日 受領)

\title{
空中散布によるダイアジノン剂の飼料作物における消失
}

\author{
河野 説一一春元 三郎・中村 信夫（宮崎県総合農業試験場）
}

\begin{abstract}
Disappearance of diazinon residue in forage crops following aerial application.
Ken'ichi Kohno, Saburo Harumoto and Nobuo Nakamura (Miyazaki Agricultural Experiment Station, Miyazaki-gun, Miyazaki 880-02)

Diazinon residues in forage crops exposed to aerial application of a mixture product of diazinon, carbaryl, and phenazine oxide were determined, and the resultant silage and milk of dairy cattle fed with $30 \mathrm{~kg}$ of the silage per day were checked for maintaining consumers safety. Residue levels of diazinon in fresh sorghum and corn decreased to $0.2-1.0 \mathrm{ppm}$ in $1 \mathrm{day}, 0.05-0.14 \mathrm{ppm}$ in 3 days, and $0.01-0.03 \mathrm{ppm}$ in 7 days, and were beyond detection limits in 14 days. No diazinon was detected in either silage or milk.
\end{abstract}

水田利用再編対策の実施に伴い，近年宮崎県では飼料 作物の生産が著しく増加しており，1978年では県内の転 作面積 10,180 ha $55 \%$ をを飼料作物が占めている。しかし ながら，水田地帯で使用した農樂の飼料作物への残留性 および畜産物への移行に関する調查事例が全国的にきわ めて少ない現状にある。

筹者らは，1978年方ら水田地带に点在する飼料作物畑 で空中散布後の青刚飼料作物における農薬の消長とサイ
レージならびに牛乳中への残留について調督し, 婴全な 飼料生産のための基礎資料を得たので報告する。なお， 試験を行うにあたり，御協力いただいた圖崎県農林航空 事業対策協議会，都城病害虫防除所ならびに都城農業改 良普及所の関係者各位に厚く謝意を表する。

\section{試験方法}

乳, 肉牛の飼育が盛んな霧島山麓に近いえびの市(1978

第1表試䟻設計およひ調查方法

\begin{tabular}{|c|c|}
\hline 調 查 地 & $\begin{array}{l}\text { I : 宫崎県北諸県郡高城町石山(ソルゴーとトウモロコシの混播) II：都娍市太郎坊（ソルゴ } \\
\text { 一), III : 都城市高榞(トウモロコシ) }\end{array}$ \\
\hline $\begin{array}{l}\text { 散布日と } \\
\text { 散布薬剂 }\end{array}$ & 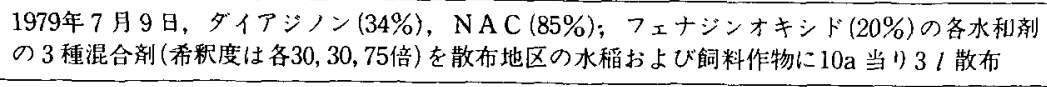 \\
\hline 調查項目 & 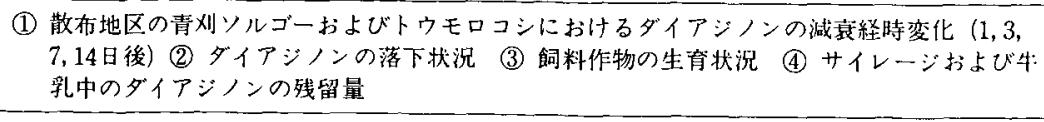 \\
\hline 部位 & (1)ソルゴー：蕉葉，子実 (2)トウモロコシ：苳葉，子実，雄䄼 (3) 牛乳：生乳 \\
\hline 分 析法 & 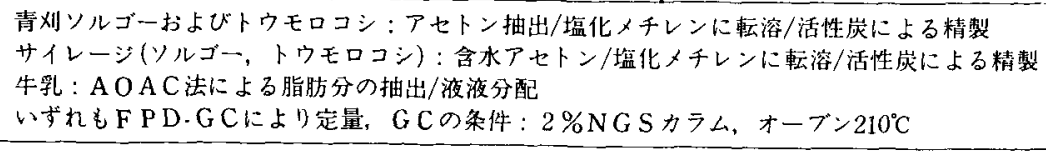 \\
\hline
\end{tabular}


年)，都城市および高城町（1979年）において，普通期 水稻への空中散布の時期に調查した。試験設計および調 查方法は第 1 表のとおりである。転作畑における飼料作 物の作付の特徽は水田に点在していることであり，水稲 に農薬の空中散布を実施する場合，やむなく飼料作物に も同様な条件で散布がなされてしまうので，水田からの 飛散とは異なり，飼料作物の農薬残留について最大量を 把握でき好都合であった。

\section{結果および考察}

空中散布によるダイアジンンの落下状洗を第 2 表に示 した。これ活，1筆の飼料作物畑 $(50 \times 20 \mathrm{~m})$ を围む両 側の晆畔上に, 直径 $8.7 \mathrm{~cm}$ のガラスシャーレをおき, ア セトンに溶解後，FPD-GC により定量する方法を採用 した。ダイアジンンの落下量は測定地点により変動して いるが，よく落下していると考元られた。飼料作物畑内 については青色るラーコート紙により調査したが，ほぼ 同様の傾向であった。

第 2 表 晆皐に扔けるダイアジノンの落下状況

\begin{tabular}{|c|c|c|c|c|c|c|}
\hline \multirow{2}{*}{ 畦 畔 名 } & \multicolumn{6}{|c|}{ ダイアジノン成分量 $\left(\mu \mathrm{g} / \mathrm{cm}^{2}\right)$} \\
\hline & 西 & 端 & 中 & 央 & 東 & 端 \\
\hline A & \multicolumn{2}{|c|}{2.32} & \multicolumn{2}{|c|}{2.40} & \multicolumn{2}{|c|}{2.83} \\
\hline B & \multicolumn{2}{|c|}{2.71} & \multicolumn{2}{|c|}{2.08} & \multicolumn{2}{|c|}{1.63} \\
\hline
\end{tabular}

調查地は高城町(第 1 表, 㖫查地のIに同し)，計算上の 理論値は $3.4 \mu \mathrm{g} / \mathrm{cm}^{2} 。$

散有後のソルゴーおよびトウモロコシにおけるダイア ジンの消長 (第 3 表) は, 散布 1 日後 $1 \mathrm{ppm}$ 前後, 3 日後 $0.05 \sim 0.14 \mathrm{ppm}, 7$ 日後 $0.01 \sim 0.03 \mathrm{ppm}$ そして14 日後には検出限界 $(0.007 \mathrm{ppm})$ 以下であった。ダィア シノンの娍衰曲線から, 散布直後の最大溑度は約 $5 \mathrm{ppm}$ と推定されるが，この結果は，1978年に垁施した散布融 後の結果（第 4 表）とよく一致した。播種時期が早いた

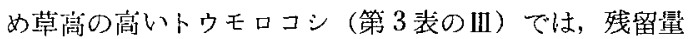
が低い傾问がみられた。またダイアジノンの減衰曲線か らみれば，ンルゴーとトウモロコシの茎葉部は酷似して

第 3 表 青刈泀料作物におけるダイアジノンの残留最

(ppm)

\begin{tabular}{|c|c|c|c|c|}
\hline \multirow{2}{*}{ 経過日数 } & ソ & $\exists-$ & \multicolumn{2}{|c|}{ トウモロコシ } \\
\hline & I & II & I & III \\
\hline 1 日 & 1.02 & 0.974 & 0.914 & 0.230 \\
\hline 3 & 0.138 & 0.120 & 0.141 & 0.052 \\
\hline 7 & 0.027 & 0.023 & 0.024 & 0.011 \\
\hline 14 & $<0.007$ & $<0.007$ & $<0.007$ & $<0.007$ \\
\hline
\end{tabular}

散布前は0.007ppm以下，IーIIIは第1表の調查地に同じ。
第 4 表 青则飼料作物における多アジノンの残留最 $(\mathrm{ppm})$

\begin{tabular}{|c|c|c|c|c|}
\hline 調＼cjkstart查 & 地 & 経過日数 & ソルゴー & $\begin{array}{l}\text { トモモ } \\
\text { ロコシ }\end{array}$ \\
\hline \multirow{3}{*}{ えU゙の市 } & 榎田 & 散布直後 & 0.360 & 0.936 \\
\hline & 西郷 & $"$ & 3.50 & 4.02 \\
\hline & $" 1$ & $"$ & - & 4.54 \\
\hline
\end{tabular}

散布日：1978年 7 月 $2 \sim 3$ 日, 草高: 0.5 1. 5m, 1978年のデー夕はこの第 4 表のみ。

いることもあり，残留消長には大きな差があるとは考え られなかった。

有機リン系殺虫剂の中では, やや残留性の高いダイア ジンがこのように速やかに消失する原因として，こ扎 らの畑の中では，通風性の悪さから通常の外気温より高 温となり蒸気圧の高いダィアジノン剤は気化による蒸発 や分解が促進され，また若い時期では，2週閒で草高が 2 倍（重量で約 8 倍と推定）に生長するため，肥大によ る希膰効果も大きいものと考えられた。

\begin{tabular}{|c|c|c|c|c|}
\hline 调查地 & $\begin{array}{l}\text { サイレ一湆 } \\
\text { の 杖 料 }\end{array}$ & 試料番号 & $\begin{array}{l}\text { 散布から } \\
\text { 牛に絵与 } \\
\text { までの日数 }\end{array}$ & $\begin{array}{l}\text { ダイアジ } \\
\text { ノン (ppm) }\end{array}$ \\
\hline 都城峝 & トウモロコシ & No. $\begin{array}{l}1 \\
2 \\
3 \\
4\end{array}$ & $\begin{array}{c}\text { 無散布 } \\
126 \\
128 \\
130\end{array}$ & $\begin{array}{l}<0.003 \\
<0.003 \\
<0.003 \\
<0.003\end{array}$ \\
\hline 高城町 & $\begin{array}{l}\text { ソルゴー } \\
\text { トウモロコシ }\end{array}$ & 5 & 145 & $<0.003$ \\
\hline
\end{tabular}

收檴およU゙+イ亿詰め No.1４：1979.8/3，№.5:9/15。

第 6 表 牛乳中におけるダイアジノンの残留量

\begin{tabular}{|c|c|c|c|}
\hline 調查地 & $\begin{array}{l}\text { 牛の種類と } \\
\text { 供試頍数 }\end{array}$ & $\begin{array}{l}\text { \#イレージ } \\
\text { 給与後の数 }\end{array}$ & $\begin{array}{r}\text { ダイヤジンン } \\
(\mathrm{ppm})\end{array}$ \\
\hline 都城市 & $\begin{array}{l}\text { ホルスタイン } \\
1 \quad \text { 頭 } \\
(\text { (体重約710kg) }\end{array}$ & $\begin{array}{l}\text { 給与前 } \\
2 \text { 日後 } \\
4 \text { 日後 } \\
6 \text { 日後 }\end{array}$ & $\begin{array}{l}<0.0005 \\
<0.0005 \\
<0.0005 \\
<0.0005\end{array}$ \\
\hline 高城町 & $\begin{array}{l}\text { ホルスタイン } \\
15 \text { 碩 } \\
\text { (平坋体重 } 600 \mathrm{~kg} \text { ) }\end{array}$ & $\begin{array}{l}\text { 給与前 } \\
1 \text { 日後 }\end{array}$ & $\begin{array}{l}<0.0005 \\
<0.0005\end{array}$ \\
\hline
\end{tabular}

第 7 莅 飼料作物の生育状況（草高, cm)

\begin{tabular}{|c|c|c|c|c|c|}
\hline \multirow{2}{*}{$\begin{array}{l}\text { 調查日 } \\
\text { 1979年 }\end{array}$} & \multirow{2}{*}{$\begin{array}{l}\text { 経 } \\
\text { 日 }\end{array}$} & \multicolumn{2}{|c|}{ ソルゴー } & \multicolumn{2}{|c|}{ トウモロコシ } \\
\hline & & I & II & I & III \\
\hline 7月 10 日 & 1 日 & 50 & 75 & 50 & 230 \\
\hline 12 & 3 & 65 & 80 & 65 & 240 \\
\hline 16 & 7 & 90 & 105 & 90 & 250 \\
\hline 23 & 14 & 110 & 145 & 110 & 260 \\
\hline
\end{tabular}

調查地（I～III）は策I表に同じ。 


\begin{tabular}{|c|c|c|c|c|c|c|}
\hline \multirow{2}{*}{ 散布地 } & \multirow{2}{*}{$\begin{array}{c}\text { 散布日の気象状況 } \\
(7 \text { 時20分散布) }\end{array}$} & \multirow[b]{2}{*}{ 散布地 } & \multicolumn{4}{|c|}{ 散布後の気奥 } \\
\hline & & & 月半旬 & $\begin{array}{l}\text { 平均 } \\
\text { 気温("C) }\end{array}$ & 降水量 $(\mathbf{m m})$ & $\begin{array}{c}\text { 降雨日数 } \\
\text { (日) }\end{array}$ \\
\hline 高城町 & $\begin{array}{l}\text { 天気:〈もり, 散布終了 } 2 \text { 時間後 } \\
\text { に約 } 10 \mathrm{~mm} \text { の降雨, } \\
\text { 風速 : } 0.5 \sim 0.6 \mathrm{~m} / \text { 秒，風向 : 北， } \\
\text { 気温 }: 20.5^{\circ} \mathrm{C} .\end{array}$ & 都城市 & $\begin{array}{r}7 . \\
2 \\
3 \\
4 \\
5\end{array}$ & $\begin{array}{l}22.2 \\
22.4 \\
26.6 \\
23.8 \\
26.3\end{array}$ & $\begin{array}{r}208 \\
29 \\
64 \\
126 \\
51\end{array}$ & $\begin{array}{l}4 \\
5 \\
2 \\
4 \\
3\end{array}$ \\
\hline
\end{tabular}

1979年 7 月 9 日散布。

次に飼料作物を収磷後サイロに詰めて賗蔵したサイ レーシ (第 5 表) では，収穫胕にダイアジノンが消失し ていたため, 当然のことながら検出されなかった。これ らのサイレージ(約 $30 \mathrm{~kg} /$ 日) を濃厚飼料 $(6 \sim 10 \mathrm{~kg} /$ 日) とともに乳牛に給与後，擦乳した牛乳（未加工の生乳） 加も第 6 表に示したように, ダイアジンは検出され ずサイレージ㧍よび濃厚飼料は，ダイアジノンによる 污染をうけていないこと方確認された。サイレーシはば イアジンンを含有していなかったため, 乳牛に給与後の 牛乳中への移行に関する試験は目的を達成できなかった が, この場合, 散布 1 日娞位の青刚飼料を給与して調查 すべきだと考えられる。

飼料作物におけるダイアシンンの残留に関する調查に ついては,ダィアジンの微粒戍または粉郕を牧草に散

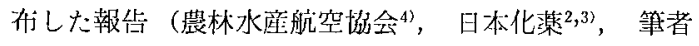
ら 1)がみられる。いずれも，散何值後の残留量は高い が，その後の消長はきわめて速い結果がでており，剂型 を買にする水和剂を使用した本斌験においても，同様の 傾向を確認した。なお，本試験では，ダイアジノンのほ かにフェナシンオキシドやカーバメート䒺の NAC も同 時に散布しているので，己れらの残留と消長については， 今後の検討が必要である。
摘要

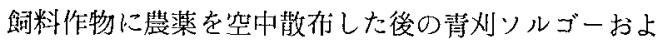
びトウモロコシとこれらのサイレージならびに乳牛に給 与後の牛乳についてダイアジンの残留を調查した結果 は，次のとおりであった。

1. 青刚ソルゴーおよびトウモロコシ中のダィアジ， ンの濃度は, 散柯 1 日後で $1 \mathrm{ppm}$ 前後を示したが, 消失 は速やかで， 2 週間後には検出されなくなった。

2. サイレージおよび特乳からは，ダイアジノンは検 出されなかった。

3. ダイアジノンといっしょに散布した NAC および フェナジンオキシドについては，今後の調查が必要であ る。

\section{引用文献}

1) 河野謙一・春元三郎・中村信夫 (1974) 総合農試た より $37: 25-26 . \quad 2)$ 日本化薬（株) (1973), ダィ

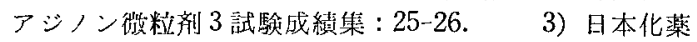
(株) (1973), ダイアジノン微精剤 1 試験成續集 : 19-20. 4）農林水産航空坫会 (1972) 昭和46年度農林水産航空 事業新分野閂発試験成績書 82:103-104.

(1980年 4 月28日 受領) 